\title{
Complementary and Alternative Treatment Methods used in Adults with Diabetes in Turkey
}

\author{
Ebru Gül andÜmmühan Aktürk* \\ Public Health Nursing, Inönü University, Turkey \\ *Corresponding author: Ümmühan Aktürk, Public Health Nursing, Inönü University, Turkey
}

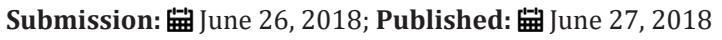

\begin{abstract}
The use of complementary and alternative medicine (CAM) is increasing worldwide. Among the most commonly used CAM treatments are nutritional supplements, herbal remedies, mental healing, naturopathy, manipulative body based therapy, energy therapy, massage therapy, hypnosis, music therapy and relaxation techniques. The use of CAM for the management of chronic diseases is becoming increasingly wide spread and its use is influenced by the health belief system, culture and tradition, ethnicity, geography and family history. Since 1990s, studies on the prevalence of CAM use among patients with diabetes mellitus are growing and the data showed that CAM is a popular choice for diabetes management. On-the-spot use of persons with diabetes associated with CAM use, there is a concern that when used as a complementary treatment there is a risk of drug interactions and additional complications.Turkey ranks third after Russia and Germany is a country in the European region with the highest diabetes. In the literature in patients with diabetes of CAM use is common in Turkey and it is supported by the studies that the most used CAM method is herbal products. The number of scientific and licensed CAM centers in Turkey is still not sufficient and the ones available are not well known by the public.It is expected that nurses will be directed to develop nursing practices related to the use of CAM, to identify effective strategies, and to use the CAM effectively and correctly.
\end{abstract}

Keywords: Diabetes; Complementary and alternative medicine; Nursing

\section{Introduction}

Specifically, type 2 diabetes carbohydrate is characterized by chronic hyperglycaemia with impaired fatty and protein metabolism. Type 2 diabetes has become an increasingly public health problem with an estimated prevalence of 285 million people globally (corresponding to $6.4 \%$ of the adult population in the world). According to the International Diabetes Federation (IDF) projections, more than 550 million people are expected to receive diabetes until 2030 [1]. The use of complementary and alternative medicine (CAM) is increasing worldwide [2]. CAM encompasses all health systems, modalities, and practices other than those intrinsic to the politically dominant health system of a particular society or culture [3]. Among the most commonly used CAM treatments are nutritional supplements, herbal remedies, mental healing, naturopathy, manipulative body based therapy, energy therapy, massage therapy, hypnosis, music therapy and relaxation techniques $[2,4]$. Due to inadequate treatment regimens available in the US, 2-3.6 million people use complementary and alternative treatment for diabetes treatment [5]. CAMs are of interest in academic, industrial and economic areas due to their high usage frequency [4]. The use of CAM for the management of chronic diseases is becoming increasingly widespread and its use is influenced by the health belief system, culture and tradition, ethnicity, geography and family history [3].
Diabetic patients, one of the chronic illnesses are often able to take supplementary treatments in addition to medical treatments. In addition, it is stated that the rate of using CAM for diabetic patients is higher than other patient groups [6]. In studies conducted all over the world, CAM use was reported for more than two-thirds of the population [7]. Since 1990s, studies on the prevalence of CAM use among patients with diabetes mellitus are growing and the data showed that CAM is a popular choice for diabetes management [3]. These patients often consult with CAM practitioners or self-manage with CAM the rapies based on their own knowledge [2]. Because diabetes is an individual and multidimensional illness and life-long illness, it is thought that individuals lead other alternative practices besides medical treatment [8]. Cinnamon, garlic preparations, cemenia and multi-vitamins are herbal products commonly used among diabetics and researches continue to have hypoglycaemic effects. Body mind applications such as yoga and tai chi are also used by diabetic patients, but the long-term effects on glycemic control are unsatisfactory [7]. Furthermore, the scientific literature on the efficacy of CAM in the treatment of diabetes is relatively infrequent and diverse. On the spot use of persons with diabetes associated with CAM use, there is a concern that when used as a complementary treatment there is a risk of drug interactions and additional complications [9]. 
Turkey ranks third after Russia and Germany is a country in the European region with the highest diabetes [10]. Patients with diabetes in studies conducted in Turkey are reported to be between $25-85 \%$ in the rate of CAM use [11]. Diabetes and other chronic diseases of plants in Turkey were reported to be the most commonly used CAM methods $[12,13]$. Plants are an important source for these new drugs along more than 400 types of plants and more than 120 natural products are used as supplements besides various vitamins and minerals for the treatment of diabetic patients [14]. The treatment of diabetes in Turkey, fenugreek, cinnamon, garlic, nigella, mulberry, olive, soya beans, blueberries, cumin, fennel, rye, kırkkilit grass, basil, yams, leeks, quince, nettle, pomegranate and okra flower widely are among the plants used [15].

In a study of 285 people by Kaynak et al. [11] $48.1 \%$ of the patients were using CAM, $67.3 \%$ of them using only herbal applications, $90.5 \%$ of them using CAM to lower blood sugar. Similarly, in a study conducted by Öztürk et al. [14] 52.1\% of the patients stated that they use one or more herbal products after the diagnosis of diabetes. In the study conducted by Küçükgüçlü et al. [12], it was determined that $88.6 \%$ of the participants stated that they had type 2 diabetes, $34.6 \%$ used CAM additionally, 94\% used vegetative treatment and $75.2 \%$ stated that they benefited from CAM [12]. In the study conducted by Candar et al. [7] 73.7\% of the CAM users stated that they use her baltreatment, 9.1\% cupping and 5.7\% use mind and body applications. In addition black cumin, cinnamon and olive leaf is the most preferred herbal products. In the study conducted by Ceylan et al. [16] 41\% of the participants used at least one type of CAM, $88.1 \%$ used her baltreatment and $31.1 \%$ of them use garden thyme [16].

In the study conducted by Oksel et al. [8] it was determined that $70.7 \%$ of the patients used alternative methods and all of the users used herbal products. Among the most used herbal products, thyme juice with $25.8 \%$, cinnamon with $17.2 \%$ and it was determined that $89.6 \%$ of the patients were using it to lower blood sugar [8]. In another study, 22\% of diabetic patients reported using her balproducts. It was determined that $5.3 \%$ of the vegetable crop users used cinnamon, $4.7 \%$ of lemon, $3.3 \%$ of pomegranate, $2.7 \%$ of greentea, $2 \%$ of almond, $1.3 \%$ of firme, sage and olive leaf tea [17]. In the work done by Sürücü et al. [13] of patients with diabetes prevalence of CAM use in Turkey is between $11.5 \%$ 70.7\% and $(70.7 \%$ ) were the most frequently used her balproducts. In the literature in patients with diabetes of CAM use is common in Turkey and it is supported by the studies that the most used CAM method is herbal products $[7,8,11-13]$. Another important point in patients with diabetes in Turkey is less of studies related to CAM use and it is note worthy that the number of CAM practitioners is inadequate.

\section{Conclusion}

The use of CAM among diabetes mellitus patients in our region is reported to be high [7]. The number of scientific and licensed CAM centers in Turkey is still not enough and is not well known by the people that are present. For this reason, most people see king methods other than traditional the rapies got ostores prepar- ing herbal preparations, although there is little vocational training [16]. In terms of physicians and diabetes educator nurses who determine the medical treatment of the patients, whether patients use CAM, it is important how the methods used affect the patient and the disease [8]. In this respect, it is recommended that diabetic patients be informed about the use of CAM by healthcare professionals. The number of scientific and licensed CAM centers in Turkey is still not sufficient and the ones available are not well known by the public. It is expected that nurses will be directed to develop nursing practices related to the use of CAM, to identify effective strategies, and to use the CAM effectively and correctly [18].

\section{References}

1. Bergman M (2014) Global health perspectives in prediabetes and diabetes prevention. World Scientific Publishing Co Pte Ltd, Singapore, 38: $1-2$.

2. Al-Eidi S, Tayel S, Al-Slail F, Qureshi NA, Sohaibani I, et al. (2016) Knowledge, attitude and practice of patients with type 2 diabetes mellitus towards complementary and alternative medicine. J Integr Med 14(3): 187-196.

3. Baharom N, Shamsul Azhar S, Rotina AB (2016) Prevalence of complementary alternative medicine use among patients with type 11 diabetes in negeri sembilan, Malaysia. Med \& Health 11(2): 257-266.

4. Medagama AB, Bandara R (2014) The use of complementary and alternative medicines (cams) in the treatment of diabetes mellitus: is continued use safe and effective? Nutrition journal 13(1): 102.

5. Ranasinghe P, Jayawardana R, Galappaththy P, Constantine GR, De Vas Gunawardana N, et al. (2012) Efficacy and safety of 'true' cinnamon (Cinnamomum zeylanicum) as a pharmaceutical agent in diabetes: a systematic review and meta-analysis. Diabet Med 29(12): 1480-1492.

6. Çalık A (2017) Diyabet tedavisinde kullamlan tamamlayicive alternatif tedaviler: literatür derlemesi. Adnan Menderes Üniversitesi Sağllk Bilimleri Fakültesi Dergisi 1(2): 79-84.

7. Candar A, Demirci H, Baran AK, Akpınar Y (2018) The association between quality of life and complementary and alternative medicine use in patients with diabetes mellitus. Complement Ther Clin Pract 31(2): $1-6$.

8. Oksel E, Şişman FN (2009) Diabetes mellitus'lu hastaların kullandıkları tamamlayıcı ve alternatif tedavi yöntemleri. Journal of Ege University Nursing Faculty 25(3): 27-36.

9. Huri HZ, Lian GTP, Hussain S, Pendek R, Widodo RT (2009) A survey amongst complementary alternative medicine (CAM) users with type 2 diabetes. Int J Diabetes \& Metabolism 17: 9-15.

10. https://www.idf.org/e-library/epidemiology-research/diabetes-atlas. html

11. Kaynak İ, Polat Ü (2017) Diabetes mellitus' lu has taların tamamlayıcı ve alternatif tedavileri kullanma durumları ve diyabet tutumları ile ilişkisi. Genel Tıp Dergisi 27(2): 56-64.

12. Küçükgüçlü Ö, Kızılcı S, Mert H, Uğur Ö, Besen DB, et al. (2012) Complementary and alternative medicine use among people with diabetes in Turkey. West J Nurs Res 34(7): 902-916.

13. Surucu H, Kizilci S, Ugur Ö (2013) Use of complementary and alternative medicine among patients with diabetes in Turkey: systematic review. Inter J Basic Clin Stud 2(2): 16-30.

14. Öztürk S, Gündogdu YP, Gürsu M, Yamak M, Özkan O, et al. (2015) Use of herbal products in type 2 diabetic patients. Haseki Tip Bulteni 53(3): 214-219. 
15. Çıkladilmez Ş (2013) Diyabet tedavisinde kullanılan bitkiler ve bitkisel ürünler. Kayseri: Erciyes Üniversitesi, Turkey.

16. Ceylan S, Azal Ö, Taşlipinar A, Türker T, Açikel CH, et al. (2009) Complementary and alternative medicine use among Turkish diabetes patients. Complement Ther Med 17(2): 78-83.

17. Pınar N, Topaloğlu M, Özsan M, Özer C, Alp H (2017) Hatay ilinde üniversite hastanesi endokrin polikliniğine başvuran diyabet hastalarının bitkisel ürün kullanımı. Konuralp Medical Journal/Konuralp Tip Dergisi 9(3): 26-30.

18. Turan N, Öztürk A, Kaya N (2010) Hemşirelikte yeni bir sorumluluk alanı: tamamlayıcı terapi. Maltepe Üniversitesi Hemşirelik Bilim ve Sanatı Dergisi 3(1): 93-108. (c) (i) Creative Commons Attribution 4.0 International License

For possible submissions Click Here
Submit Article

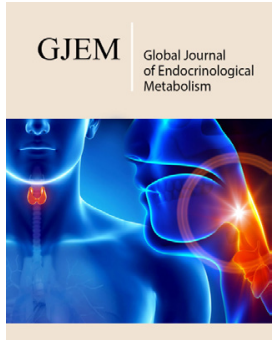

Global Journal of Endlocrinological Metabolism

\section{Benefits of Publishing with us}

- High-level peer review and editorial services

- Freely accessible online immediately upon publication

- Authors retain the copyright to their work

- Licensing it under a Creative Commons license

- Visibility through different online platforms 